\title{
Study of Expanded Austenite Formed in Plasma Nitrided AISI 316L Samples, Using Synchrotron Radiation Diffraction
}

\author{
Marcelo Campos $^{a, b *}$, Sylvio Dionysio de Souza ${ }^{a, c}$, Luis Gallego Martinez ${ }^{d}$, Maristela Olzon- Dionysio ${ }^{a, c}$ \\ ${ }^{a}$ Departamento de Física, Universidade Federal de São Carlos - UFSCar, São Carlos, SP, Brasil \\ ${ }^{b}$ Embrapa Instrumentação, Empresa Brasileira de Pesquisa Agropecuária, São Carlos, SP, Brasil \\ 'Instituto de Ciências e Tecnologia, Universidade Federal dos Vales do \\ Jequitinhonha e Mucuri-UFVJM, Diamantina, MG, Brasil \\ ${ }^{d}$ Centro de Ciência e Tecnologia de Materiais, Instituto de Pesquisas Energéticas e Nucleares - IPEN, \\ São Paulo, SP, Brasil
}

Received: April 7, 2014; Revised: October 9, 2014

\begin{abstract}
AISI 316L stainless steel samples nitrided at different conditions of temperature and time, showing different properties, such as nitrogen concentration $\left(\mathrm{C}_{\mathrm{N}}\right)$ and nitrided layer thickness, were studied. Expanded austenite $\left(\gamma_{N}\right)$ diffraction peaks up to the $(222)$ reflection were observed using suitable wavelength synchrotron radiation. XRD patterns were fitted by Le Bail method, using a special triclinic crystal structure (with a lattice distortion $\eta$ ) for $\gamma_{N}$, whose peaks were decomposed in a few subpeaks, to consider $\mathrm{C}_{\mathrm{N}}$ gradient across the nitrided layer. Our results indicate that regarding $\gamma_{\mathrm{N}}$ magnetic behavior, which was observed for the samples nitrided at $450{ }^{\circ} \mathrm{C}$, it seems to be correlated not only to high $\mathrm{C}_{\mathrm{N}}$ ( $\geq 31$ at.\%), but also to higher $\eta\left(\geq 2.4^{\circ}\right.$ ), which reaches up to $5.6^{\circ}$. This distortion $\eta$ decreases when $C_{N}$ increases, consequently, with its minimum close to the surface. On the other hand, for paramagnetic samples $\left(350^{\circ} \mathrm{C}\right), \eta$ increases up to $1.4^{\circ}$ when $\mathrm{C}_{\mathrm{N}}$ increases up to 30 at. $\%$.
\end{abstract}

Keywords: AISI 316L stainless steel, plasma nitriding, expanded austenite, layer depth, synchrotron diffraction, magnetic character

\section{Introduction}

Plasma nitriding of stainless steels improves some of their tribological properties ${ }^{1-5}$ as a result of the nitrided layer, which is formed on the surface, whose properties depend strongly on the conditions used in the process, such as gas composition and pressure, temperature and time. If the temperature is lower than $450{ }^{\circ} \mathrm{C}$, an expanded austenite phase $\left(\gamma_{\mathrm{N}}\right)$, which presents a large nitrogen concentration, is formed. This layer shows higher hardness and higher pitting corrosion resistance in comparison with the untreated austenite $(\gamma)^{[6-9]}$.

Compared to $\gamma$ reflections, $\gamma_{\mathrm{N}}$ peaks are broader and shifted to lower diffraction angles. The $\gamma_{\mathrm{N}}(200)$ positions are more deviated relatively to the $\gamma(200)$ diffraction angle than the other planes, demonstrating a deviation from the cubic fcc unit cell. The structure of this phase is still a matter of controversy which has not yet been completely clarified ${ }^{10-15}$. Fewel et al. ${ }^{10}$ employed both $\mathrm{Cu}-\mathrm{K} \alpha$ and $\mathrm{Co}-\mathrm{K} \alpha$ radiations to measure X-ray Diffraction (XRD) patterns up to the (420) reflection for one selected nitrided sample. They analyzed the XRD patterns trying different structures, like tetragonal, monoclinic and triclinic, obtaining the best agreement of their data for the latter one. Particularly, it is a structure which presents a low symmetry, but they used to represent it as a fcc structure with distortion. To do this, the lattice parameters are equal and a distortion $\varepsilon$ (in this paper $\eta$ will be used for this distortion, not to be confused with $\varepsilon$ phase).

*e-mail: marcelobtu@gmail.com
This model was tested by Mingolo et al. ${ }^{14}$, who used $\mathrm{Cu}-\mathrm{K} \alpha$ to measure a lower number of reflections, up to (400). They studied the $\gamma_{N}$ phase observed for the surface of two AISI 316L nitrided samples, describing it well by a triclinic structure, instead of tetragonal or monoclinic. In a more recent study of seven nitrided samples using synchrotron radiation diffraction, Fewell and Priest ${ }^{15}$ observed peaks up to (622) reflection. In their study, they tested a total of ten plausible candidate structures in order to propose a structure for this phase. They examined in details two of the seven samples and concluded that none of the candidate structures work well at high order reflections and each presents its particular difficulties at a lower order. However, they affirm [...] the triclinic lattice has the 3 fewest deformation-split components of the candidate structures and generally the highest multiplicity component of a reflection correspond to the measured position [...]"15 prior to the (440) reflections. For the current study, as the use of synchrotron radiation allows for both a higher intensity and a better resolution, it was chosen for measuring XRD patterns up to the (222) reflection, from eight nitrided AISI 316L samples. The samples were nitrided at different conditions of time and temperature, and consequently, showed different properties, such as nitrogen concentration and nitrided layer thickness. In this study it was used a photon energy of $6.5 \mathrm{keV}$, whose XRD patterns were fitted using Fewell's model. Moreover, to consider nitrogen concentration gradient across the nitrided layer, each $\gamma_{\mathrm{N}}$ peak 
was decomposed in a few subpeaks, following the proposal of Öztürk and Williamson ${ }^{16}$.

\section{Material and Methods}

Details of the preparation of the samples, which were plasma nitrided using $80 \% \mathrm{H}_{2}-20 \% \mathrm{~N}_{2}$, at 6 Torr, for 3 and $5 \mathrm{~h}$ using different temperatures $\left(350,400\right.$ and $\left.450{ }^{\circ} \mathrm{C}\right)$, have been given previously ${ }^{17}$, and the nitrided layer thickness $(\mathbf{t})$ values are presented in Table 1 . Here results for samples nitrided for $4 \mathrm{~h}$, using 400 and $450{ }^{\circ} \mathrm{C}$ are presented as well.

The phases formed on the nitrided samples were characterized by XRD, performed at the Brazilian Synchrotron Light Laboratory (LNLS), using synchrotron radiation $(\lambda=1.9074 \AA$ or $\mathrm{E}=6.5001 \mathrm{keV})$. The conditions were: $\theta-2 \theta$ geometry, at $0.2^{\circ}$ steps, ranging from $47^{\circ} \leq$ $2 \theta \leq 135^{\circ}$. A pyrolytic graphite analyzer and scintillation counter were used to obtain high signal to background with medium resolution.

In addition to the austenitic matrix and $\gamma_{\mathrm{N}}$ phase, the hexagonal $\varepsilon\left(\mathrm{Fe}_{2-3} \mathrm{~N}\right)$ was used in the XRD pattern fittings and, when necessary, cubic $\gamma^{\prime}\left(\mathrm{Fe}_{4} \mathrm{~N}\right)$ and trigonal $\mathrm{Cr}_{2} \mathrm{~N}$ phases were used as well. The Le Bail technique was used to index the diffraction peaks in the experimental data ${ }^{18,19}$, which were fitted using GSAS software ${ }^{20}$ and EXPGUI graphical interface ${ }^{21}$.

For the $\gamma_{N}$ phase, having special triclinic symmetry ${ }^{10,15}$, which presents a slight distortion $(\eta)$ from fcc austenitic substrate structure was used. Based on the results of Öztürk and Williamson ${ }^{16}$, we concluded that the best model to adopt in $\gamma_{N}$ phase fittings was to consider it as a solid solution with a sequence of layers showing different contents of nitrogen. Each layer corresponds to a different lattice parameter $a \gamma_{N}$. The values for nitrogen concentration in each solid $\gamma_{N}$ phases, $\mathbf{C}_{\mathbf{N}}$, were calculated using Picard's equation ${ }^{22}$

$a \gamma_{N}=a \gamma+\alpha C_{N}$

where $\alpha$ is a constant. The literature indicates a range of values for this constant, which depends on the $\mathbf{C}_{\mathbf{V}}$ value $^{16}$. The most commonly used ( $\alpha=0.0078 \AA /$ at. $\% \mathrm{~N})$ is known as Vegard's constant ${ }^{14,23}$. Instead of this value, a different value is indicated, because the last one is used for low nitrogen concentrations (0-10 at. $\%)$. The new value is ${ }^{16,24}$, $\alpha=0.00861 \AA /$ at.\% N, which was adopted in this work.

\section{Results and Discussion}

Figure 1a presents the measured XRD patterns. The vertical bars show the positions of the fcc austenite peaks, labeled $\gamma(\mathrm{hkl})$. All the XRD patterns show the expanded austenitic $\gamma_{\mathrm{N}}$ peaks, which are broader and shifted to lower diffraction angles, when compared to the correspondent austenite peaks. Figure $1 \mathrm{~b}$ presents the penetration depth (d) of the synchrotron radiation.
The diffraction patterns presented in Figure 1 show a positive correlation between this penetration depth (d) of radiation and the nitrided layer thicknesses $(\mathbf{t})$ (Table 1).

The $\gamma(111)$ reflection whose $\mathbf{d}$ value $(10.4 \mu \mathrm{m})$ is minimum, is observed for 350 and $400^{\circ} \mathrm{C}$, whose thickness is $\mathbf{t}<10.4 \mu \mathrm{m}$. Moreover, the $\gamma(111)$ intensity decreases when $\mathbf{t}$ increases, and is significantly higher than that of $\gamma_{\mathrm{N}}(111)$ for $350{ }^{\circ} \mathrm{C}$, $3 \mathrm{~h}$, whose $\mathbf{t}=0.7 \mu \mathrm{m}$. The intensity decreases substantially at $400{ }^{\circ} \mathrm{C}(2.9 \leq \mathbf{t} \leq 3.9 \mu \mathrm{m})$ and practically disappears at $450{ }^{\circ} \mathrm{C}$, with $7.6 \leq \mathbf{t} \leq 11 \mu \mathrm{m}$, i.e., $\mathbf{t} \sim \mathbf{d}$. On the other hand, if we analyze the reflections of higher order, i.e., (311), where $\mathbf{d} \sim 20 \mathrm{~mm}$, the $\gamma(311)$ intensity is comparable for 350 and $400{ }^{\circ} \mathrm{C}$, which show $\mathbf{t}<\mathbf{d} / 7$, but diminishes considerably at $450{ }^{\circ} \mathrm{C}$, showing $\mathbf{t} \sim \mathbf{d} / 2$.

Figure 2 shows the fitted diffraction lines (in red) on data points (black circles) for the samples nitrided for $3 \mathrm{~h}$. In order to see details of all the reflections on the XRD patterns, Figures $3 \mathrm{a}, \mathrm{b}$ and $\mathrm{c}$ present a zoomed image from the region between $80^{\circ}$ and $135^{\circ}$ of Figure 2, showing all the phases which were used in the fittings. This region was selected because of the significative separation of the different $\gamma_{N}$ phases, which is not observed in (111) and (200) reflections. Figure 4 illustrates details of the subpeaks, which were used for considering nitrogen concentration gradient across the nitrided layer.

\subsection{Samples nitrided at $350^{\circ} \mathrm{C}$}

Whereas three different $\gamma_{N}$ phases were used in fittings for the samples nitrided for $3 \mathrm{~h}$, four phases were used for 5h sample. The austenite $\left(a_{\gamma}=3.597 \AA\right)$ and the $\varepsilon$ phases were used as well. The fitted values for the $\gamma_{\mathrm{N}}$ phases are presented in Table 2.

\subsection{Samples nitrided at $400^{\circ} \mathrm{C}$}

Four different $\gamma_{\mathrm{N}}$ phases were used in the fittings for the samples nitrided for $3 \mathrm{~h}$, while five phases were used for 4 and 5 h samples. The austenite $\left(a_{\gamma}=3.597 \AA\right)$ and the $\varepsilon$ phases were used, as well as for $350{ }^{\circ} \mathrm{C}$. In Table 3 are presented the fitted values for the $\gamma_{\mathrm{N}}$ phases.

For both temperatures, an additional phase appears for $5 \mathrm{~h}$, compared to $3 \mathrm{~h}$. This phase represents $25 \%$ (or $1 / 4$ ) and $20 \%$ (or $1 / 5$ ) of the total number used for $\gamma_{N}$ subphases, for 350 and $400{ }^{\circ} \mathrm{C}$, respectively. This rise can be explained by the increase of $23 \%$ and $21 \%$ (from 3 to $5 \mathrm{~h}$, for 350 and $400{ }^{\circ} \mathrm{C}$, respectively) of nitrided layer thicknesses $(\mathbf{t})$. This is because all the diffusion layers (and even the matrix) are certainly observed, as the x-ray penetration depth (d) complies with the equation $3.0 \mathrm{t} \leq \mathrm{d} \leq 27 \mathrm{t}$. In this equation, the minimum corresponds to (111) reflection, for $400{ }^{\circ} \mathrm{C}$, $5 \mathrm{~h}$ and the maximum, to $(222)$, for $350^{\circ} \mathrm{C}, 3 \mathrm{~h}$. Moreover, as this additional phase presents lower $\mathrm{N}$ concentrations, it is located in the innermost layer, which is known as the diffusion layer.

Table 1. Thickness (t) of the samples' nitrided layers ${ }^{17}$.

\begin{tabular}{ccccccccc}
\hline Temperature $\left({ }^{\circ} \mathbf{C}\right)$ & & 350 & & 400 & & \multicolumn{4}{c}{} \\
\hline Time $(\mathrm{h})$ & 3 & 5 & 3 & 4 & 5 & 3 & 4 & 5 \\
$\underline{\mathbf{t}}(\mu \mathrm{m})$ & $0.77 \pm 0.04$ & $1.0 \pm 0.1$ & $2.9 \pm 0.4$ & $3.9 \pm 0.4$ & $3.5 \pm 0.4$ & $7.6 \pm 0.2$ & $10 \pm 1$ & $11 \pm 1$ \\
\hline
\end{tabular}




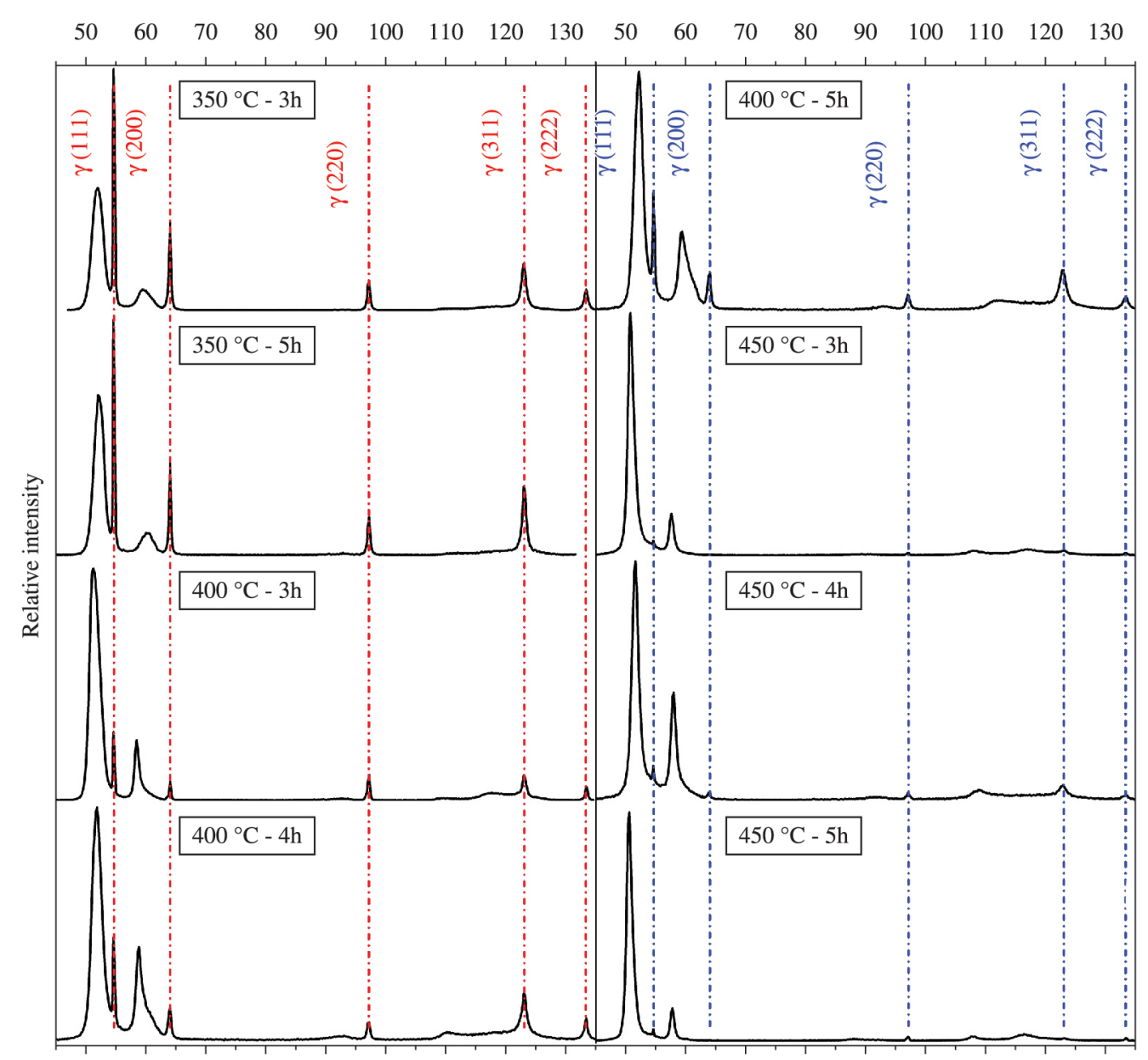

(a)

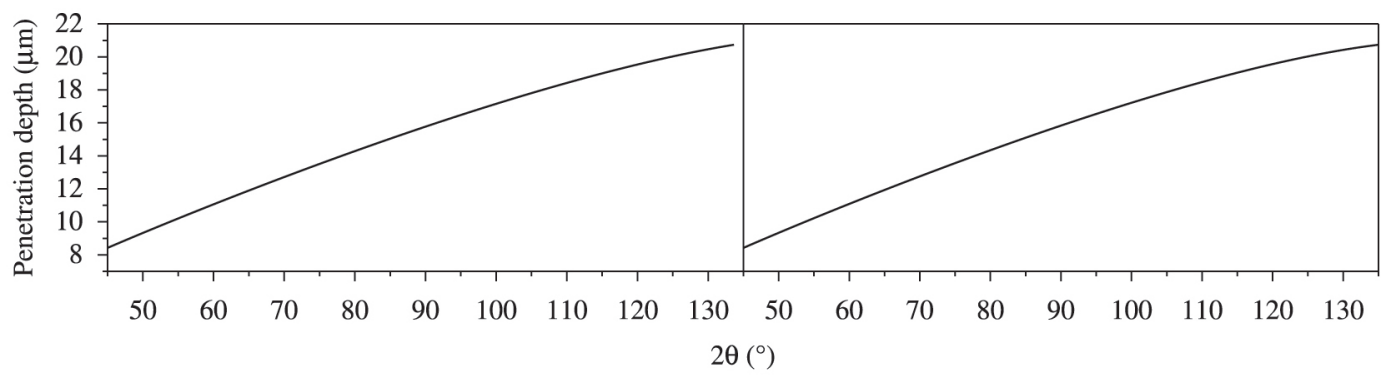

(b)

Figure 1. (a) X-ray diffraction patterns of the samples nitrided at different temperatures and times and (b) Synchrotron radiation (6.5keV) penetration depth (d) as a function of the diffracted angle.

\subsection{Samples nitrided at $450^{\circ} \mathrm{C}$}

Four different $\gamma_{N}$ phases were used in the fittings for the samples nitrided for all times: 3, 4 and $5 \mathrm{~h}$. In addition to the austenite $\left(a_{\gamma}=3.597 \AA\right), \varepsilon$ and $\gamma^{\prime}$ phases, the $\mathrm{Cr}_{2} \mathrm{~N}$ phase was used as well. Table 4 presents the fitted values for the $\gamma_{\mathrm{N}}$ phases.

These samples differ from the 350 and $400{ }^{\circ} \mathrm{C}$ samples in at least two different aspects. The first one is the same number of $\gamma_{\mathrm{N}}$ phases used in the fittings, for all times: 3, 4 and $5 \mathrm{~h}$. The second one is the $\gamma_{\mathrm{N}}$ phase concentration, whose minimum value is 31 at.\%. For these samples, the interval that correlates $\mathbf{t}$ and $\mathbf{d}$ is $0.95 \mathrm{t} \leq \mathrm{d} \leq 2.7 \mathrm{t}$; consequently, the observation of the diffusion layer may be much more difficult. Another possible and more likely explanation is that the diffusion layer might be less significant, relatively to 350 and $400{ }^{\circ} \mathrm{C}$, as it decreases with the increasing the temperature, according to some authors ${ }^{25,26}$.

It can be seen from the data in Tables 2 and 4 that while $\mathbf{C}_{\mathbf{N}} \leq 30$ at. $\%$, for $350{ }^{\circ} \mathrm{C}$ samples, $\mathbf{C}_{\mathbf{N}} \geq 31$ at. $\%$ for $450{ }^{\circ} \mathrm{C}$ samples. It is likely that this behavior is related with the magnetic character of the $\gamma_{\mathrm{N}}$ phase, since it is known that 


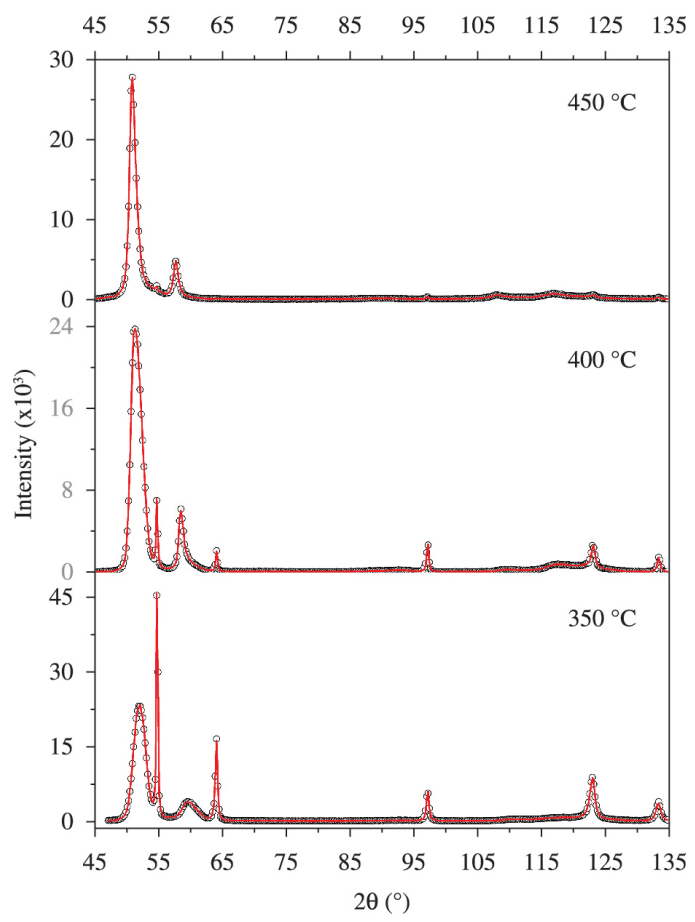

Figure 2. Fitted X-ray diffraction patterns for the samples nitrided for $3 \mathrm{~h}$ at different temperatures. this phase is paramagnetic (or magnetic) when its $\mathbf{C}_{\mathbf{v}}$ is low (high) ${ }^{16}$. The Mössbauer Spectroscopy can show this behavior, and the results for all the samples will be presented in a future publication. If this is assumed, it is interesting to show that the lattice distortion $\eta$ behavior in relation to $\mathbf{C}_{\mathrm{N}}$ depends on the magnetic character of the respective $\gamma_{\mathrm{N}}$ phase. To evidence this aspect, Figure 5 shows $\eta$ values as a function of $\mathbf{C}_{\mathbf{v}}$ values, i.e., the fourth column as a function of the last column of Tables 2, 3 and 4.

This figure presents two very distinct regions: $\mathbf{C}_{\mathbf{v}} \leq 30$ at.\% (which is marked in a vertical dotted line), showing $\eta \leq 1.4^{\circ}$ (in a horizontal dotted line, below) and the second one, indicating $\mathbf{C}_{\mathbf{N}} \geq 31$ at. $\%$ and $\eta \geq 2.4^{\circ}$ (in a horizontal dotted line, above), where the samples nitrided at 350 and $450{ }^{\circ} \mathrm{C}$, respectively, can be observed and each one shows a typical behavior.

The paramagnetic $\gamma_{N}$ phases in layers nitrided at $350{ }^{\circ} \mathrm{C}$, for 3 and $5 \mathrm{~h}$, are very similar, showing a very high $\mathbf{C}_{\mathbf{v}}$ gradient (approximately 60 at.\%) between the inner region and the surface. At the same time, the lattice distortion $\eta$ increases when $\mathbf{C}_{\mathbf{N}}$ increases, and therefore it is higher near the surface, showing a slight variation, approximately $0.8^{\circ}$. On the other hand, the magnetic layers nitrided at $450{ }^{\circ} \mathrm{C}$ show a very different behavior: while the $\mathbf{C}_{\mathbf{N}}$ gradient between the inner region and the surface is much smaller, showing a 20 to 30 at.\% variation, the lattice

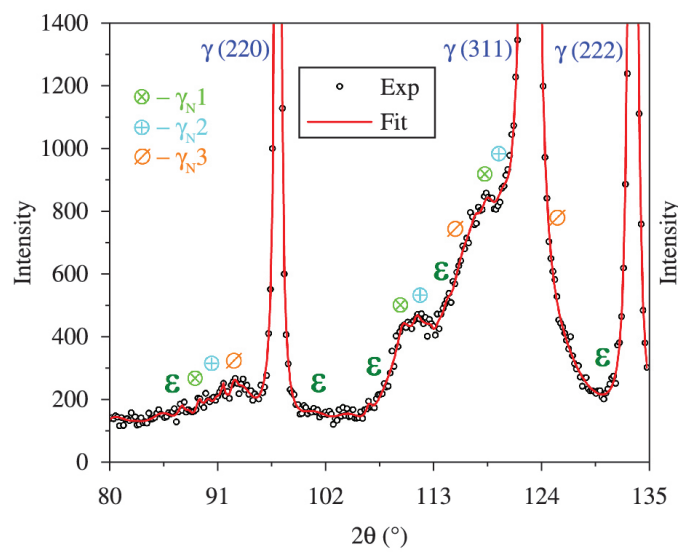

(a)

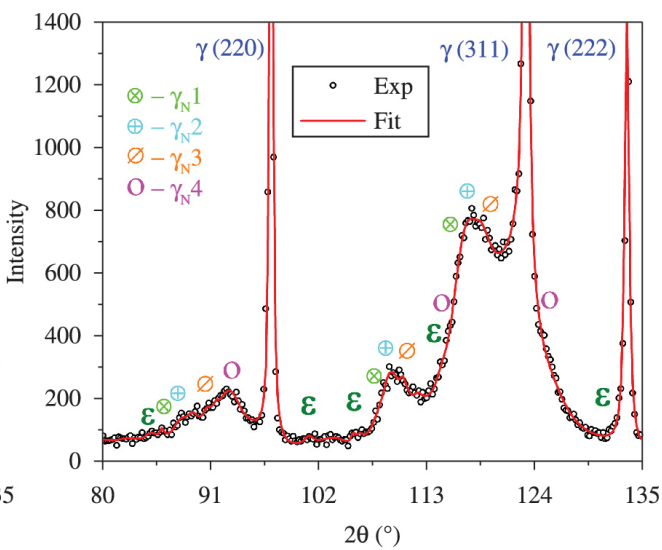

(b)

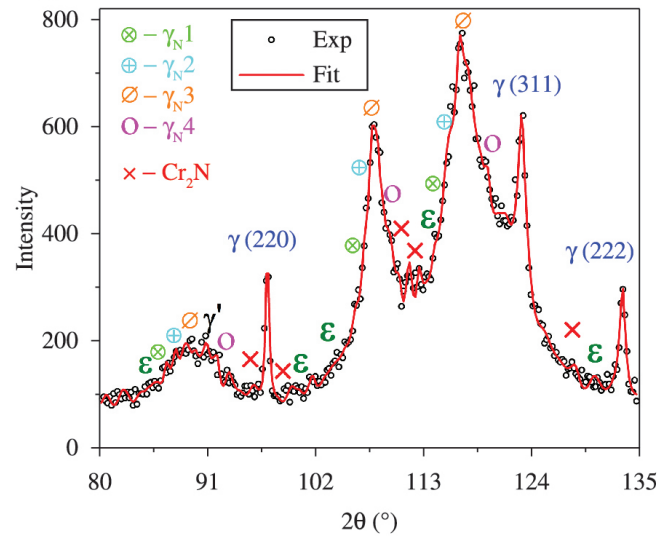

(c)

Figure 3. Zoom of the region between (220) and (222) reflections of Figure 3, for (a) 350, (b) 400 and (c) $450{ }^{\circ} \mathrm{C}$. 


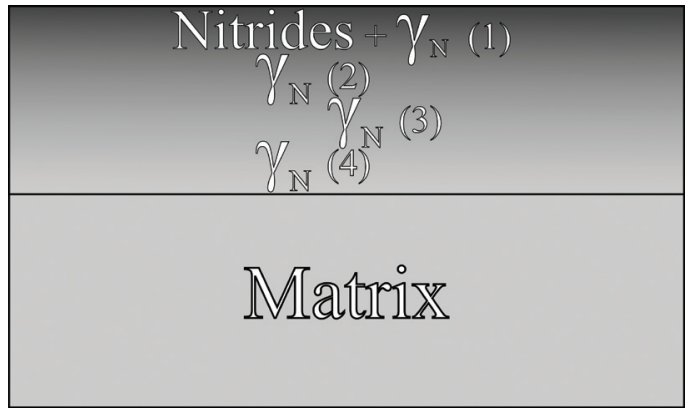

Figure 4. Illustration of the subpeaks used for the $\gamma_{\mathrm{N}}$ fittings.

Table 2. Values for Lattice parameter (a), Distortion $(\eta)$ and Nitrogen concentration $\left(\mathbf{C}_{\mathrm{N}}\right)$ for each sublayer of the $\gamma_{\mathrm{N}}$ phases used in DRX pattern fittings for samples nitrided at $350^{\circ} \mathrm{C}$.

\begin{tabular}{ccccc}
\hline$\gamma_{\mathbf{N}}$ & & $\mathbf{a}_{\gamma \mathbf{N}}(\mathbf{( 0 . 0 1 )} \AA$ & $\eta(\mathbf{( 0 . 1})^{\circ}$ & $\mathbf{C}_{\mathbf{N}}(\mathbf{\pm}) \mathbf{a t .} \%$ \\
\hline $350{ }^{\circ} \mathrm{C}$ & 1 & 3.86 & 1.4 & 30 \\
$3 \mathrm{~h}$ & 2 & 3.80 & 1.2 & 23 \\
& 3 & 3.74 & 0.6 & 16 \\
$350{ }^{\circ} \mathrm{C}$ & 1 & 3.85 & 1.3 & 29 \\
$5 \mathrm{~h}$ & 2 & 3.82 & 1.3 & 26 \\
& 3 & 3.78 & 1.1 & 21 \\
& 4 & 3.74 & 0.6 & 16 \\
\hline
\end{tabular}

Table 3. Values for Lattice parameter (a), Distortion $(\eta)$ and Nitrogen concentration $\left(\mathbf{C}_{N}\right)$ for each sublayer of the $\gamma_{N}$ phases used in DRX pattern fittings for samples nitrided at $400{ }^{\circ} \mathrm{C}$.

\begin{tabular}{ccccc}
\hline$\gamma_{\mathbf{N}}$ & & $\mathbf{a}_{\gamma \mathbf{N}}(\mathbf{( 0 . 0 1}) \boldsymbol{\AA}$ & $\eta \mathbf{( \pm \mathbf { 0 . 1 }})^{\circ}$ & $\mathbf{C}_{\mathbf{N}}(\mathbf{\pm} \mathbf{3}) \mathbf{a t .} \%$ \\
\hline $400{ }^{\circ} \mathrm{C}$ & 1 & 3.92 & 2.2 & 37 \\
$3 \mathrm{~h}$ & 2 & 3.91 & 3.0 & 36 \\
& 3 & 3.87 & 2.9 & 31 \\
& 4 & 3.77 & 1.3 & 20 \\
$400{ }^{\circ} \mathrm{C}$ & 1 & 3.90 & 2.3 & 35 \\
$4 \mathrm{~h}$ & 2 & 3.89 & 3.1 & 34 \\
& 3 & 3.80 & 2.7 & 23 \\
& 4 & 3.74 & 1.1 & 16 \\
$400{ }^{\circ} \mathrm{C}$ & 1 & 3.87 & 2.8 & 12 \\
$5 \mathrm{~h}$ & 2 & 3.84 & 2.7 & 28 \\
& 3 & 3.77 & 1.5 & 20 \\
& 4 & 3.74 & 1.6 & 16 \\
& 5 & 3.71 & 1.8 & 13 \\
\hline
\end{tabular}

distortion $\eta$, which is maximum in the inner region, shows a variation between $1.3^{\circ}$ and $2.4^{\circ}$ for 5 and $3 \mathrm{~h}$, respectively. For $4 \mathrm{~h}$, while $\mathbf{C}_{\mathbf{N}}$ shows the highest interval, between 31 and 43 at. $\%, \eta$ shows a very smooth variation of $0.7^{\circ}$. Moreover, Williamson and Öztürk ${ }^{16}$ suggested that the magnetic $\gamma_{\mathrm{N}}$ phase is analogous to the fcc ordered $\gamma^{\prime}-\mathrm{Fe}_{4} \mathrm{~N}$, which has a more expanded fcc lattice compared with $\gamma$-Fe and is ferromagnetic at room temperature. In this respect, our results seem to agree with their suggestion, because lattice distortion $\eta$ decreases when $\mathbf{C}_{\mathbf{N}}$ increases, near the
Table 4. Values for Lattice parameter (a), Distortion $(\eta)$ and Nitrogen concentration $\left(\mathbf{C}_{N}\right)$ for each sublayer of the $\gamma_{N}$ phases used in DRX pattern fittings for samples nitrided at $450{ }^{\circ} \mathrm{C}$.

\begin{tabular}{ccccc}
\hline$\gamma_{\mathbf{N}}$ & & $\mathbf{a}_{\gamma \mathbf{N}}(\mathbf{( 0 . 0 1 )} \AA$ & $\eta(\mathbf{( 0 . 1})^{\circ}$ & $\mathbf{C}_{\mathbf{N}}(\mathbf{\pm}) \mathbf{a t .} \%$ \\
\hline $450{ }^{\circ} \mathrm{C}$ & 1 & 3.98 & 3.2 & 44 \\
$3 \mathrm{~h}$ & 2 & 3.96 & 3.8 & 42 \\
& 3 & 3.94 & 4.9 & 39 \\
& 4 & 3.91 & 5.6 & 36 \\
$450{ }^{\circ} \mathrm{C}$ & 1 & 3.97 & 4.1 & 43 \\
$4 \mathrm{~h}$ & 2 & 3.95 & 4.4 & 41 \\
& 3 & 3.92 & 4.8 & 37 \\
$450{ }^{\circ} \mathrm{C}$ & 1 & 3.96 & 4.9 & 31 \\
$5 \mathrm{~h}$ & 2 & 3.95 & 2.4 & 42 \\
& 3 & 3.92 & 2.9 & 41 \\
& 4 & 3.87 & 3.7 & 37 \\
\hline
\end{tabular}

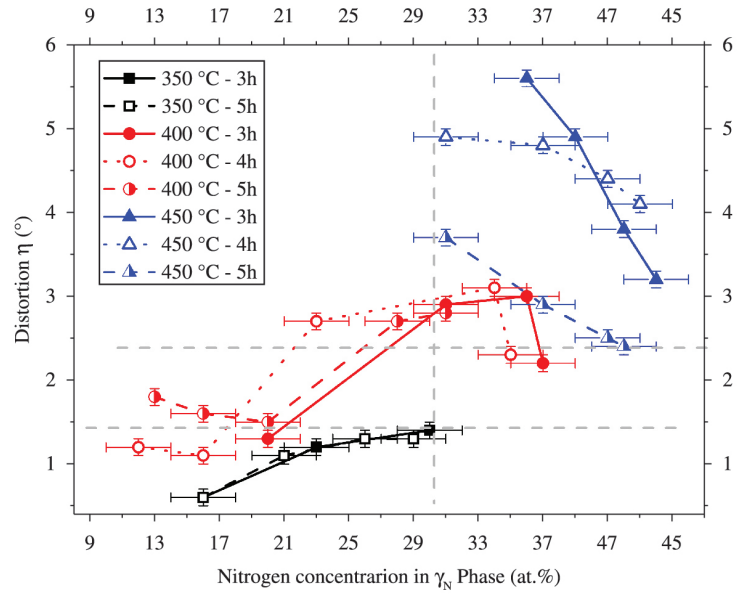

Figure 5. Lattice distortion as a function of nitrogen concentration for each sublayer of the $\gamma_{\mathrm{N}}$ phases used in DRX patterns fittings, for all the nitrided samples.

surface, for $450{ }^{\circ} \mathrm{C}$ samples, indicating a higher symmetry for the subphase which is more magnetic. Therefore, our assumption seems to be correct.

Regarding the samples nitrided at $400{ }^{\circ} \mathrm{C}$, they show magnetism and paramagnetism simultaneously ${ }^{9}$, and are magnetic near the surface and paramagnetic in the inner region, which can be observed in Figure 5. This figure indicates that the behavior of these samples is not uniform as is for the samples nitrided at 350 and $450{ }^{\circ} \mathrm{C}$. However, the $\gamma_{\mathrm{N}}$ phases presenting $\mathbf{C}_{\mathrm{N}}$ in the same interval observed for $350{ }^{\circ} \mathrm{C}$ samples, i.e., for $17 \leq \mathbf{C}_{\mathbf{N}} \leq 30$ at. $\%$, show the same behavior observed for these samples. In other words, the lattice distortion $\eta$ increases when $\mathbf{C}_{\mathbf{N}}$ increases, although it increases to $3.0^{\circ}$, which is significantly higher than the value observed for the $350{ }^{\circ} \mathrm{C}$ samples, i.e., $1.4^{\circ}$. On the other hand, for $\mathbf{C}_{\mathbf{v}} \geq 31$ at. $\%$, for both 3 and $4 \mathrm{~h}$, for the most superficial layer, $\eta$ decreases to a value very close to $2.4^{\circ}$, which is the $\eta$ reference value for the samples nitrided at $450{ }^{\circ} \mathrm{C}$. 


\section{Conclusion}

1) Regarding $\gamma_{\mathrm{N}}$ phases magnetic character, our results indicate that magnetic behavior, observed for the samples nitrided at $450{ }^{\circ} \mathrm{C}$, seems to be correlated not only with high nitrogen concentration $\left(\mathbf{C}_{\mathbf{N}} \geq 31\right.$ at.\%), but also with high lattice distortion $\left(\eta \geq 2.4^{\circ}\right)$, which reached up to $5.6^{\circ}$. Moreover, this distortion decreases when $\mathbf{C}_{\mathbf{N}}$ increases, consequently it has a minimum value at the surface.

2) On the other hand, for paramagnetic samples, nitrided at $350{ }^{\circ} \mathrm{C}$, the lattice distortion $\eta$ increases when $\mathbf{C}_{\mathbf{N}}$

\section{References}

1. Williamson DL, Öztürk O, Wei R and Wilbur PJ. Metastable phase formation and enhanced diffusion in f.c.c. alloys under high dose, high flux nitrogen implantation at high and low ion energies. Surface and Coatings Technology. 1994; 65(1-3):1523. http://dx.doi.org/10.1016/S0257-8972(94)80003-0.

2. Menthe E, Bulak A, Olfe J, Zimmermann A and Rie K-T. Improvement of the mechanical properties of austenitic stainless steel after plasma nitriding. Surface and Coatings Technology. 2000; 133-134:259-263. http://dx.doi.org/10.1016/ S0257-8972(00)00930-0.

3. Liang W. Surface modification of AISI 304 austenitic stainless steel by plasma nitriding. Applied Surface Science. 2003; 211(1-4):308-314. http://dx.doi.org/10.1016/S01694332(03)00260-5.

4. Li G, Peng Q, Li C, Wang Y, Gao J, Chen S, et al. Effect of DC plasma nitriding temperature on microstructure and drysliding wear properties of $316 \mathrm{~L}$ stainless steel. Surface and Coatings Technology. 2008; 202(12):2749-2754. http://dx.doi. org/10.1016/j.surfcoat.2007.10.002.

5. Xi Y, Liu D and Han D. Improvement of corrosion and wear resistances of AISI 420 martensitic stainless steel using plasma nitriding at low temperature. Surface and Coatings Technology. 2008; 202(12):2577-2583. http://dx.doi.org/10.1016/j. surfcoat.2007.09.036.

6. Olzon-Dionysio M, de Souza SD, Basso RLO and de Souza S. Application of Mössbauer spectroscopy to the study of corrosion resistance in $\mathrm{NaCl}$ solution of plasma nitrided AISI 316L stainless steel. Surface and Coatings Technology. 2008; 202(15):3607-3614. http://dx.doi.org/10.1016/j. surfcoat.2007.12.040.

7. Fossati A, Borgioli F, Galvanetto E and Bacci T. Corrosion resistance properties of glow-discharge nitrided AISI 316L austenitic stainless steel in $\mathrm{NaCl}$ solutions. Corrosion Science. 2006; 48(6):1513-1527. http://dx.doi.org/10.1016/j. corsci.2005.06.006.

8. Li CX and Bell T. Corrosion properties of active screen plasma nitrided 316 austenitic stainless steel. Corrosion Science. 2004; 46(6):1527-1547. http://dx.doi.org/10.1016/j. corsci.2003.09.015.

9. Campos M, de Souza SD, de Souza S and Olzon-Dionysio M. Improving the empirical model for plasma nitrided AISI 316L corrosion resistance based on Mössbauer spectroscopy. Hyperfine Interactions. 2011; 203(1-3):105-112. http://dx.doi. org/10.1007/s10751-011-0351-3.

10. Fewell MP, Mitchell DRG, Priest JM, Short KT and Collins GA. The nature of expanded austenite. Surface and increases, up to $1.4^{\circ}$ and 30 at.\%, respectively. In this case, it has a maximum at the surface.

3) As the sample set showed a big range of layer thickness, this property was correlated to X-ray depths penetration from different reflections of XRD patterns, showing significant positive correlation between both.

\section{Acknowledgements}

This work was partly supported by the Brazilian research funding agencies FAPESP and CAPES. We gratefully acknowledge the National Laboratory of Light Synchrotron - LNLS, Brazil Grant No. XDR1/9101.

Coatings Technology. 2000; 131(1-3):300-306. http://dx.doi. org/10.1016/S0257-8972(00)00804-5.

11. Blawert C, Mordike BL, Jirásková Y and Schneeweiss O. Structure and composition of expanded austenite produced by nitrogen plasma immersion ion implantation of stainless steels X6CrNiTi1810 and X2CrNiMoN2253. Surface and Coatings Technology. 1999; 116-119:189-198. http://dx.doi.org/10.1016/ S0257-8972(99)00086-9.

12. Blawert C, Kalvelage H, Mordike BL, Collins GA, Short KT, Jirásková Y, et al. Nitrogen and carbon expanded austenite produced by PI3. Surface and Coatings Technology. 2001; 136(1-3):181-187. http://dx.doi.org/10.1016/S02578972(00)01050-1.

13. Gontijo LC, Machado R, Miola EJ, Casteletti LC, Alcântara NG and Nascente PAP. Study of the S phase formed on plasma-nitrided AISI 316L stainless steel. Materials Science and Engineering A. 2006; 431(1-2):315-321. http://dx.doi. org/10.1016/j.msea.2006.06.023.

14. Mingolo N, Tschiptschin AP and Pinedo CE. On the formation of expanded austenite during plasma nitriding of an AISI 316L austenitic stainless steel. Surface and Coatings Technology. 2006; 201(7):4215-4218. http://dx.doi.org/10.1016/j. surfcoat.2006.08.060.

15. Fewell MP and Priest JM. High-order diffractometry of expanded austenite using synchrotron radiation. Surface and Coatings Technology. 2008; 202(9):1802-1815. http://dx.doi. org/10.1016/j.surfcoat.2007.07.062.

16. Öztürk $\mathrm{O}$ and Williamson DL. Phase and composition depth distribution analyses of low energy, high flux $\mathrm{N}$ implanted stainless steel. Journal of Applied Physics. 1995; 77(8):38393850. http://dx.doi.org/10.1063/1.358561.

17. Olzon-Dionysio M, Campos M, Higa OZ, Cunha TF and Souza SD. Investigating the correlation between some of the properties of plasma nitrided AISI 316L stainless steel. Materials Research. 2013; 16(5):1052-1057. http://dx.doi. org/10.1590/S1516-14392013005000081.

18. Le Bail A, Duroy H and Fourquet JL. Ab-initio structure determination of LiSbWO6 by X-ray powder diffraction. Materials Research Bulletin. 1988; 23(3):447-452. http:// dx.doi.org/10.1016/0025-5408(88)90019-0.

19. Le Bail A. Whole powder pattern decomposition methods and applications: A retrospection. Powder Diffraction. 2005; 20(4):316-326. http://dx.doi.org/10.1154/1.2135315.

20. Larson AC and Von Dreele RB. General Structure Analysis System (GSAS). Los Alamos: Los Alamos National Laboratory; 2004. Los Alamos National Laboratory Report, LAUR-86-748. 
21. Toby BH. EXPGUI, a graphical user interface for GSAS. Journal of Applied Crystallography. 2001; 34(2):210-213. http://dx.doi.org/10.1107/S0021889801002242.

22. Picard S, Memet JB, Sabot R, Grosseau-Poussard JL, Rivière JP and Meilland R. Corrosion behaviour, microhardness and surface characterisation of low energy, high current ion implanted austenitic stainless steel. Materials Science and Engineering A. 2001; 303(1-2):163-172. http://dx.doi. org/10.1016/S0921-5093(00)01841-4.

23. Jack DH and Jack KH. Invited review: Carbides and nitrides in steel. Materials Science and Engineering. 1973; 11(1):1-27. http://dx.doi.org/10.1016/0025-5416(73)90055-4.
24. Ledbetter HM and Austin MW. Dilation of an fcc $\mathrm{Fe}-\mathrm{Cr}-\mathrm{Ni}$ alloy by interstitial carbon and nitrogen. Materials Science and Technology. 1987; 3(2):101-104. http://dx.doi.org/10.1179/ mst.1987.3.2.101.

25. Borgioli F, Fossati A, Galvanetto E and Bacci T. Glowdischarge nitriding of AISI $316 \mathrm{~L}$ austenitic stainless steel: influence of treatment temperature. Surface and Coatings Technology. 2005; 200(7):2474-2480. http://dx.doi. org/10.1016/j.surfcoat.2004.07.110.

26. Li Y, Wang L, Xu J and Zhang D. Plasma nitriding of AISI 316L austenitic stainless steels at anodic potential. Surface and Coatings Technology. 2012; 206(8-9):2430-2437. http:// dx.doi.org/10.1016/j.surfcoat.2011.10.045. 